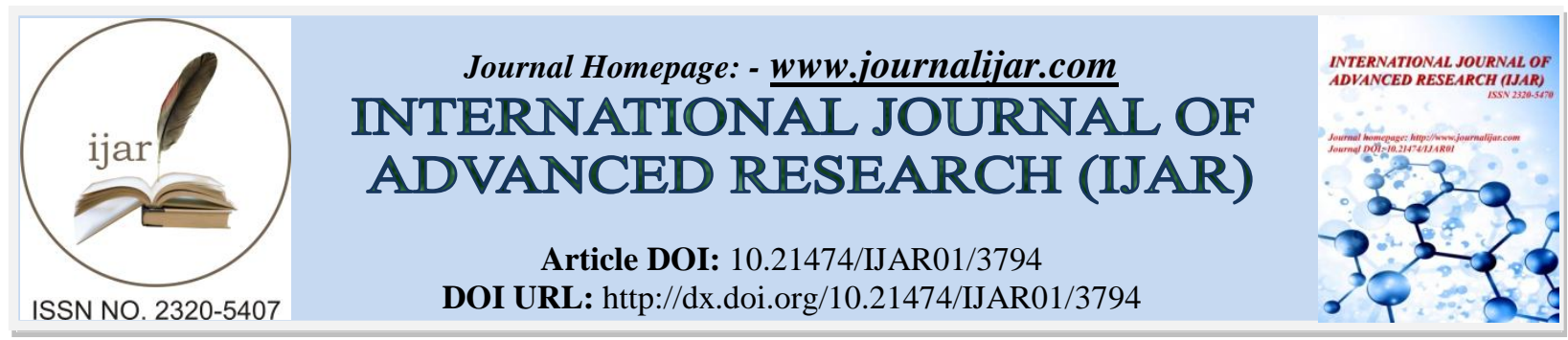

RESEARCH ARTICLE

\title{
LEVERAGE OF SYNTHETIC VITAMINS (C AND E) ON ANTIOXIDANT ACTIVITY IN BROILERS CHALLENGED WITH $E$. COLI.
}

\author{
Rasha F. Muhammad ${ }^{1}$, Aida H. Soliman ${ }^{1}$ and Essam S. Soliman ${ }^{2 *}$. \\ 1. Department of Chemistry, Faculty of Science, Suez Canal University, Ismailia, Egypt 41522. \\ 2. Department of Animal Hygiene, Zoonosis \& Animal Behavior, Faculty of Veterinary Medicine, Suez Canal \\ University, Ismailia, Egypt 41522.
}

\section{Manuscript Info \\ Manuscript History \\ Received: 11 February 2017 \\ Final Accepted: 02 March 2017 \\ Published: April 2017}

Key words:-

Broilers, E. coli, Synthesis, Vitamin C, Vitamin E.

\begin{abstract}
Vitamin $\mathrm{E}$ as a lipid component of biological membranes is known to be a major chain-breaking antioxidant and vitamin $\mathrm{C}$ or ascorbic acid is an anti-oxidant which is normally synthesized by the chicken. A comparative study was carried out to demonstrate the influence of synthesized vitamin $\mathrm{C}$ and vitamin $\mathrm{E}$ on bird performance, biochemical, antioxidant and immunological status. 150 broiler chick was received from day one age; divided into three groups; G1 (supplemented with synthetized vitamin C $3.5 \mathrm{~g} / 1 \mathrm{~L}$ water); G2 (supplemented with synthetized vitamin E $1 \mathrm{~mL} / 1 \mathrm{~L}$ water) and G3 (Control). G1 and G2 were challenged at $2^{\text {nd }}$ week of age with E. coli $\mathrm{O}_{157}: \mathrm{H}_{7} 1.3 \times 10^{6} \mathrm{CFU}$. A total of 180 samples (60 serum, 60 plasma and 60 intestinal swab) were collected during the study period. The results revealed that both synthetized vitamin $\mathrm{E}$ and vitamin $\mathrm{C}$ were able to enforce a protective effect in the birds last for only 4 week then vanished gradually. Synthetized vitamin $\mathrm{E}$ was superior to the vitamin $\mathrm{C}$ in enforcing a good protective effect on the birds as vitamin $\mathrm{E}$ showed more prominent stimulation of immunoglobulin (IgG; $\operatorname{IgM}$. IgE) and bacterial counts were reduced significantly compared to the influence of vitamin C. The study concluded the necessity of the treatment continuation in order to maintain the enhancing effect on antioxidant enzymatic activity and protective immunological effect.
\end{abstract}

Copy Right, IJAR, 2017,. All rights reserved.

\section{Introduction:-}

Vitamin E has a great ability in enhancing quality and minimize lipid oxidation in broilers (Rey et al., 2015). Some naturally existing compounds may have the same activity of vitamin $\mathrm{E}$ as $\alpha-, \beta-, \gamma-$, and $\delta$-tocopherols and $\alpha$-, $\beta$-, $\gamma$-, and $\delta$-tocotrienols (Voljč et al., 2011) especially $\alpha$-tocopherol; which is more active and widely distributed (Halliwell and Gutteridge, 2000). DL- $\alpha$-tocopherol acetate that contain the eight stereoisomers is commonly used as a vitamin E supplement in poultry farms to enhance the bird's growth and their meat quality. D- $\alpha$-tocopherol had a superiority in bioavailability than the synthetic DL- $\alpha$-tocopherol acetate (Lauridsen et al., 2002), also it was able to alleviate lipopolysaccharide-induced inflammatory response (Kaiser $\boldsymbol{e t}$ al., 2012), and improving meat quality and muscular antioxidant capacity.

Corresponding Author:- Essam S. Soliman.

Address:- Department of Animal Hygiene, Zoonosis \& Animal Behavior, Faculty of Veterinary 
Vitamin $\mathrm{C}$ strongly recommended in poultry industry to alleviate stress. Although the birds were able to synthetize its own requirement of vitamin $\mathrm{C}$, but during stress the requirements may exceed the synthetizing ability of the birds. Vitamin $\mathrm{C}$ supplementation in diets have many beneficial influences on blood parameters of broilers raised under heat stress (Ghazi et al., 2015). Vitamin C improved performance traits (body weight, body weight gain, feed conversion ratio, and performance index) and blood metabolites which in turn suppressed the negative effects of heat stress (Rafiee et al., 2016).

The excited environmental stressors as heat stress (Altan et al., 2003), high ammonia concentration, as well as cold stress (Bottje et al., 1998), contributed the shifting of oxidant-antioxidant equilibrium to a pro-oxidative status (Sahin et al., 2002). Depending on this fact; dietary supplementation of broilers with vitamin E, and vitamin C enabled the birds to restore xanthine activity (XO) without affecting NAD (P) H-oxidase (NOX) activity or Nitric oxide (NO) bioavailability. Xanthine activity (XO) may have the ability to produce superoxide and uric acid, and buffered the effects of superoxide in broilers grown under hypoxic condition (Bautista-Ortega et al., 2014).

The present study aims to evaluate the influence of supplementary synthetized vitamins (Vitamin C and E) on antioxidant activity [Superoxide Dismutase (SOD), Glutathione Peroxidase (GSH-Px) and Glutathione Reductase (GSH-Rx)], Blood chemistry and microbial load before and after challenging broilers with E. coli.

\section{Material and Methods:-}

Experimental birds and design:-

150 broilers (one day old chicks) were purchased and habituated under the same environmental conditions. The birds were divided into three groups (G1, G2, and G3) according to the supplemented growth promoters (vitamins). G1 was supplemented with synthetized vitamin C (3.5 g / $1 \mathrm{~L}$ water) and G2 was supplemented with synthetized vitamin $\mathrm{E}\left(1 \mathrm{~mL} / 1 \mathrm{~L}\right.$ water), and G3 was kept as control. G1 and G2 were challenged with E. coli $\mathrm{O}_{157}: \mathrm{H}_{7}$ strain (ATCC ${ }^{\text {тм }}$ 700728). The culture was diluted and added by $1.3 \mathrm{X} 10^{6} \mathrm{CFU} / \mathrm{mL}$ in drinking water.

\section{Vitamins:-}

Vitamin E ( $\alpha$-tocopherol) was synthetized according to Odinokov $\boldsymbol{e t}$ al., (2003). They considered the possibility of preparing $\alpha$-tocopherol-chromanols and chromenols analoges using the double bond in the side chain. The selective ozonolysis of these compounds resulted in analogs of $\alpha$-tocopherol with an $\omega$-functionalized side chain serving as synthons for $\alpha$-tocopherol. Vitamin C was prepared as recommended by Davey, et al., (2000); Agius et al., (2003); Tripathi et al., (2009) depending on the new direction of organic chemistry in the use of polyhydroxylated tetranolactone. Both chemical compounds were identified chemically for confirmation using UV, IR and refractive index for synthetized vitamin $\mathrm{E}$ and melting point for synthetized vitamin $\mathrm{C}$.

\section{Sampling and sample preparation:-}

A total of 180 samples (60 serum, 60 plasma, and 60 intestinal swab) were collected in the study period. The samples were collected on a weekly basis starting from $2^{\text {nd }}$ week of age (zero sample), and three post challenge sample collections (P1, P2, and P3).

Serum blood samples (60 samples) were left in a cool dry place for three hours, centrifuged at $3500 \mathrm{rpm} / 5 \mathrm{~min}$. Serum samples were separated in Eppendorf tubes of $3 \mathrm{~mL}$ capacity and kept frozen until examination for biochemical and immunological parameter. Biochemical assay for Total Protein (TP); Albumin (ALB); liver enzymes including Alanine aminotransferase (ALT); Aspartate aminotransferase (AST); Triglycerides (TG); Cholesterol (CHOL); Urea; Creatinine and Glucose (Gluc) was carried out calometerically using UV1100 spectrophotometer; Young, (1995-2001). Meanwhile, Immunological assay was carried out on serum samples for IgG, IgM, IgE using DIFFU plate method; Berne, (1974), Heremans and Masson, (1973).

Whole blood samples (60 samples) were centrifuged at $4000 \mathrm{rpm} / 10 \mathrm{~min}$; aspirate off the plasma and stored at -80 ${ }^{\circ} \mathrm{C}$. The erythrocytes were washed 3 - 4 times with $5 \mathrm{~mL}$ saline $0.9 \%$ solution with centrifugation after each wash at $4000 \mathrm{rpm} / 10 \mathrm{~min}$. Finally the washed erythrocytes were resuscitated in cold distilled water, and the lysate were stored at $-80{ }^{\circ} \mathrm{C}$ for anti-oxidant assay including Superoxide Dismutase; SOD according to Nishikimi et al., (1972), Glutathione Peroxidase; GSH-Px according to Paglia and Valentine, (1967). and Glutathione Reductase; GSH-Rx according to Goldberg and Spooner, (1983). 
Intestinal swab (60 samples) were prepared by transferring $1 \mathrm{~mL}$ aseptically to a test tube containing $9 \mathrm{~mL}$ sterile $0.1 \%$ buffered peptone water $(\mathrm{w} / \mathrm{v})$ to prepare a dilution of $10^{-1}$, from which a tenfold decimal serial dilution up to $10^{-6}$ were prepared to cover the expected range of contamination which could be easily counted. The dilutions were subjected to bacterial counts including Total Bacterial Count (TBC) and Total Enterobacteriaceae Count (TEC).

\section{Bacterial Counts:-}

Total Bacterial Count (TBC): The number of Aerobic spore forming micro-organisms in intestinal swab samples was counted by drop Plate Method Zelver et al., (1999) and Herigstad et al., (2001) using standard plat count agar. The inoculated as well as un-inoculated plates were inverted and incubated at $37{ }^{\circ} \mathrm{C}$ for $24-48$ hrs. Counting the colonies on the plates showed 30 - 300 colonies per plate; Cruickshank et al., (1975, 1980).

Total Enterobacteriaceae Count (TEC): Enterobacteriaceae were counted by drop Plate Method Zelver et al., (1999) and Herigstad et al., (2001) using Eosine Methylene Blue Agar (EMB). Plates were inverted and incubated at $37{ }^{\circ} \mathrm{C}$ for 24 - 48 hours. Counting the colonies on the plates showed 30 - 300 colonies per plate; Cruickshank et al., (1975, 1980). Further identification may be recommended using pure colonies on nutrient slant that were extracted through using five typical colonies were selected and cultured onto Mac-Conkey agar plates, and incubated at $37^{\circ} \mathrm{C}$ for $24 \mathrm{hrs}$, pure colonies on Mac-Conkey agar plates were inoculated onto nutrient slant and incubated at $37^{\circ} \mathrm{C}$ for $24 \mathrm{hrs}$.

\section{Statistical Analysis:-}

Statistical analysis was run through SPSS (version, 20) for windows Levesque, (2007). The obtained data were analyzed statistically using factorial experiments of Analysis of Variance (ANOVA) for all tested groups, time and their interactions. Correlation coefficient was calculated to determine the influence of bacterial count on immunoglobulin ( $\operatorname{IgG}, \operatorname{IgM}$, and $\operatorname{Ig} \mathrm{A})$ and antioxidant activity.

\section{Results:-}

Proteinogram as shown in Table 1, revealed that Total Protein and Globulins had a non-significant decrease $(\mathrm{P}>0.05)$ in $\mathrm{G} 1, \mathrm{G} 2$ compared to control; while Albumin showed a significant increase $(\mathrm{P} \leq 0.05)$ in $\mathrm{G} 2$ and a highly significant increase $(\mathrm{P}<0.01)$ in $\mathrm{G} 1$ compared to control. The liver and kidney profile in Table 2; revealed a nonsignificant decrease $(\mathrm{P}>0.05)$ in ALT in G1 and a non-significant increase $(\mathrm{P}>0.05)$ in $\mathrm{G} 2$ compared to control, while AST showed a significant increase $(\mathrm{P} \leq 0.05)$ in $\mathrm{G} 1$ and a significant decrease $(\mathrm{P} \leq 0.05)$ in $\mathrm{G} 2$ compared to control. On the other hand Urea showed a non-significant decrease $(\mathrm{P}>0.05)$ in $\mathrm{G} 2$ and a non-significant increase $(\mathrm{P}>0.05)$ in $\mathrm{G} 1$ compared to control, while Creatinine showed a non-significant increase $(\mathrm{P}>0.05)$ in all groups to control.

Lipid profile in Table 3; revealed a non-significant increase ( $\mathrm{P}>0.05)$ in Triglycerides in $\mathrm{G} 2$ and a non-significant decrease $(\mathrm{P}>0.05)$ in $\mathrm{G} 1$, while Cholesterol showed a non-significant increase $(\mathrm{P}>0.05)$ in $\mathrm{G} 1$, G2 compared to control. Glucose showed a non-significant decrease $(\mathrm{P}>0.05)$ in $\mathrm{G} 1$ and a non-significant increase $(\mathrm{P}>0.05)$ in $\mathrm{G} 2$.

Antioxidant in Table 4; revealed that Glutathione Peroxidase had a non-significant increase (P>0.05) in G1 and a non-significant decrease $(\mathrm{P}>0.05)$ in $\mathrm{G} 2$; Glutathione Reductase showed a non-significant increase $(\mathrm{P}>0.05)$ in $\mathrm{G} 1$, G2 compared with control, while Superoxide Dismutase showed a significant decrease $(\mathrm{P} \leq 0.05)$ at $\mathrm{G} 1$ and a significant increase $(\mathrm{P} \leq 0.05)$ in $\mathrm{G} 2$ compared to control. Immunoglobulin $\mathrm{IgG}$ showed a significant increase $(\mathrm{P} \leq 0.05)$ in $\mathrm{G} 1$ compared with control in Table (5) and a highly significant increase $(\mathrm{P}<0.01)$ in $\mathrm{G} 2$, IgM showed a highly significant decrease $(\mathrm{P}<0.01)$ in all groups compared to control and IgE showed a non-significant decrease $(\mathrm{P}>0.05)$ in $\mathrm{G} 1$ and a non-significant increase $(\mathrm{P}>0.05)$ in $\mathrm{G} 2$ compared to control. In Table 5; TBC showed a highly significant increase $(\mathrm{P}<0.01)$ in $\mathrm{G} 1$ and a non-significant decrease $(\mathrm{P}>0.05)$ in $\mathrm{G} 2$ compared to control; while TEC showed a non-significant increase $(\mathrm{P}>0.05)$ in all groups compared to control.

Vitamin $\mathrm{C}$ correlations revealed in Table 6; TBC had a highly significant intermediate negative correlation $(\mathrm{r}=-$ 0.599; $\mathrm{P}<0.01)$ with Glutathione Peroxidase and a non-significant intermediate positive correlation $(\mathrm{r}=0.465$; $\mathrm{P}>0.05)$ with Glutathione Reductase. TEC showed a non-significant intermediate positive correlation $(\mathrm{r}=0.469$; $\mathrm{P}>0.05$ ) with Glutathione Peroxidase; (Table 7). TEC showed a non-significant intermediate positive correlation $(\mathrm{r}=$ 0.484 ; $\mathrm{P}>0.05)$ with $\mathrm{IgG}$, significant intermediate positive correlation $(\mathrm{r}=0.588 ; \mathrm{P} \leq 0.05)$ with $\operatorname{IgM}$ and a highly significant strong positive correlation $(\mathrm{r}=0.923 ; \mathrm{P}<0.01)$ with $\mathrm{IgE}$. 
Vitamin E revealed in Table 7; TBC showed a non-significant intermediate positive correlation $(\mathrm{r}=0.501 ; \mathrm{P}>0.05)$ with Glutathione Peroxidase, a significant intermediate negative correlation $(\mathrm{r}=-0.625 ; \mathrm{P} \leq 0.05)$ with $\mathrm{IgG},(\mathrm{r}=-$ 0.585; $\mathrm{P} \leq 0.05)$ with $\operatorname{IgM}$ and $(\mathrm{r}=-0.648 ; \mathrm{P} \leq 0.05)$ with $\mathrm{IgE}$. TEC revealed a non-significant intermediate negative correlation $(\mathrm{r}=-0.401 ; \mathrm{P}>0.05)$ with Glutathion Peroxidase and a significant intermediate positive correlation $(\mathrm{r}=$ $0.583 ; \mathrm{P} \leq 0.05)$ with $\mathrm{IgE}$.

Table 1:- Biochemical changes in proteinogram of supplemented groups of birds against E. coli challenge.

\begin{tabular}{|r|c|c|c|}
\hline Time & $\begin{array}{c}\text { Total protein } \\
\text { g /dl }\end{array}$ & $\begin{array}{c}\text { Albumin } \\
\text { g/dl }\end{array}$ & $\begin{array}{c}\text { Globulin } \\
\text { g /dl }\end{array}$ \\
\hline G1 & $19.4217 \pm 2.765^{\mathrm{a}}$ & $1.7867 \pm 0.082^{\mathrm{a}}$ & $17.6350 \pm 2.741^{\mathrm{a}}$ \\
\hline G2 & $16.0542 \pm 3.076^{\mathrm{a}}$ & $1.2973 \pm 0.213^{\mathrm{bc}}$ & $14.7569 \pm 3.0666^{\mathrm{a}}$ \\
\hline G3 & $25.5482 \pm 3.465^{\mathrm{a}}$ & $1.1582 \pm 0.168^{\mathrm{c}}$ & $24.3900 \pm 3.404^{\mathrm{a}}$ \\
\hline
\end{tabular}

G1: birds supplemented with synthetized vitamin C (3.5 g / L).

G2: birds supplemented with synthetized vitamin E $(1 \mathrm{ml} / \mathrm{L})$.

G3: control group

Means carrying different superscripts in the same column are significantly different at $(\mathrm{P} \leq 0.05)$ or highly significantly different at $(\mathrm{P}<0.01)$.

Means carrying the same superscripts in the same column are non-significantly different at $(\mathrm{P}>0.05)$.

Table 2:- Biochemical changes in liver and kidney enzymes of supplemented groups of birds against $E$. coli challenge.

\begin{tabular}{|c|c|c|c|c|}
\hline Time & $\begin{array}{c}\text { ALT } \\
\mathbf{U} / \mathbf{L}\end{array}$ & $\begin{array}{c}\text { AST } \\
\mathbf{U} / \mathbf{L}\end{array}$ & $\begin{array}{c}\text { Urea } \\
\mathbf{m g} / \mathbf{d l}\end{array}$ & $\begin{array}{c}\text { Creatinine } \\
\text { mg / dl }\end{array}$ \\
\hline G1 & $1.2533 \pm 0.293^{\mathrm{a}}$ & $8.1958 \pm 2.945^{\mathrm{a}}$ & $20.0346 \pm 2.346^{\mathrm{a}}$ & $1.0217 \pm 0.214^{\mathrm{a}}$ \\
\hline G2 & $2.4000 \pm 0.426^{\mathrm{a}}$ & $2.2167 \pm 0.484^{\mathrm{b}}$ & $18.4854 \pm 2.525^{\mathrm{a}}$ & $1.1404 \pm 0.295^{\mathrm{a}}$ \\
\hline G3 & $2.3467 \pm 0.716^{\mathrm{a}}$ & $3.4708 \pm 1.081^{\mathrm{ab}}$ & $19.3129 \pm 3.459^{\mathrm{a}}$ & $0.7973 \pm 0.168^{\mathrm{a}}$ \\
\hline
\end{tabular}

G1: birds supplemented with synthetized vitamin C (3.5 g / L).

$\mathrm{G} 2$ : birds supplemented with synthetized vitamin $\mathrm{E}(1 \mathrm{ml} / \mathrm{L})$.

G3: control group

Means carrying different superscripts in the same column are significantly different at $(\mathrm{P} \leq 0.05)$ or highly significantly different at $(\mathrm{P}<0.01)$.

Means carrying the same superscripts in the same column are non-significantly different at $(\mathrm{P}>0.05)$.

Table 3. Biochemical changes in lipid profile and glucose of supplemented groups of birds against $E$. coli challenge.

\begin{tabular}{|c|c|c|c|}
\hline Time & $\begin{array}{c}\text { Triglycerides } \\
\text { mg / dl }\end{array}$ & $\begin{array}{c}\text { Cholesterol } \\
\text { mg / dl }\end{array}$ & $\begin{array}{c}\text { Glucose } \\
\text { mg / dl }\end{array}$ \\
\hline G1 & $218.82 \pm 22.566^{\mathrm{a}}$ & $1083.0 \pm 1.322^{\mathrm{a}}$ & $315.44 \pm 42.958^{\mathrm{a}}$ \\
\hline G2 & $257.32 \pm 16.247^{\mathrm{a}}$ & $932.1 \pm 1.088^{\mathrm{a}}$ & $500.25 \pm 99.851^{\mathrm{a}}$ \\
\hline G3 & $235.82 \pm 33.689^{\mathrm{a}}$ & $1055.4 \pm 1.507^{\mathrm{a}}$ & $338.97 \pm 45.637^{\mathrm{a}}$ \\
\hline \multicolumn{4}{|c|}{$\begin{array}{l}\text { G1: birds supplemented with synthetized vitamin } \mathrm{C}(3.5 \mathrm{~g} / \mathrm{L}) \text {. } \\
\text { G2: birds supplemented with synthetized vitamin } \mathrm{E}(1 \mathrm{ml} / \mathrm{L}) \text {. } \\
\text { G3: control group } \\
\text { Means carrying different superscripts in the same column are significantly different at }(\mathrm{P} \leq 0.05) \text { or highly } \\
\text { significantly different at }(\mathrm{P}<0.01) \text {. } \\
\text { Means carrying the same superscripts in the same column are non-significantly different at }(\mathrm{P}>0.05) \text {. }\end{array}$} \\
\hline
\end{tabular}

Table 4. Antioxidant enzymatic changes of supplemented groups of birds against $E$. coli challenge.

\begin{tabular}{|c|c|c|c|}
\hline Time & $\begin{array}{l}\text { GSH-Px } \\
\text { mU / mL }\end{array}$ & $\begin{array}{c}\text { GSH-Rx } \\
\text { U / L }\end{array}$ & $\begin{array}{c}\text { SOD } \\
\mathbf{U} / \mathbf{m L}\end{array}$ \\
\hline G1 & $2705.6 \pm 6.363^{\mathrm{a}}$ & $2962.3 \pm 3.950^{\mathrm{a}}$ & $2035.9 \pm 5.678^{b}$ \\
\hline G2 & $238.3 \pm 3.975^{\mathrm{a}}$ & $3340.8 \pm 3.996^{\mathrm{a}}$ & $6935.0 \pm 1.358^{\mathrm{a}}$ \\
\hline G3 & $1400.6 \pm 3.135^{\mathrm{a}}$ & $2694.4 \pm 6.139^{\mathrm{a}}$ & $4164.1 \pm 9.350^{\mathrm{ab}}$ \\
\hline \multicolumn{4}{|c|}{$\begin{array}{l}\text { G1: birds supplemented with synthetized vitamin } \mathrm{C}(3.5 \mathrm{~g} / \mathrm{L}) \text {. } \\
\mathrm{G} 2 \text { : birds supplemented with synthetized vitamin } \mathrm{E}(1 \mathrm{ml} / \mathrm{L}) \text {. } \\
\text { G3: control group } \\
\text { Means carrying different superscripts in the same column are significantly different at }(\mathrm{P} \leq 0.05) \text { or highly }\end{array}$} \\
\hline
\end{tabular}


significantly different at $(\mathrm{P}<0.01)$.

Means carrying the same superscripts in the same column are non-significantly different at $(\mathrm{P}>0.05)$.

Table 5. Immunological and bacteriological changes of supplemented groups of birds against $E$. coli challenge.

\begin{tabular}{|c|c|c|c|c|c|}
\hline \multirow[t]{2}{*}{ Time } & \multicolumn{3}{|c|}{ Immunoglobulin } & \multicolumn{2}{|c|}{ Bacterial Count } \\
\hline & $\begin{array}{c}\text { IgG } \\
\text { mg / dl }\end{array}$ & $\begin{array}{l}\text { IgM } \\
\text { mg / dl }\end{array}$ & $\begin{array}{c}\text { IgE } \\
\text { IU / mL }\end{array}$ & $\begin{array}{c}\text { TBC } \\
\text { CFU / mL }\end{array}$ & $\begin{array}{c}\text { TEC } \\
\text { CFU / mL }\end{array}$ \\
\hline G1 & $8.2167 \pm 0.509^{\mathrm{ab}}$ & $4.1750 \pm 0.528^{b}$ & $15.4833 \pm 4.227^{\mathrm{a}}$ & $378.58 \pm 7.912^{\mathrm{a}}$ & $482.92 \pm 1.415^{\mathrm{a}}$ \\
\hline G2 & $11.1500 \pm 2.083^{\mathrm{a}}$ & $6.6167 \pm 1.670^{b}$ & $23.5333 \pm 4.938^{\mathrm{a}}$ & $113.66 \pm 4.114^{\mathrm{b}}$ & $928.33 \pm 5.020^{\mathrm{a}}$ \\
\hline G3 & $5.6333 \pm 0.676^{\mathrm{b}}$ & $13.7500 \pm 2.649^{\mathrm{a}}$ & $17.5833 \pm 2.445^{\mathrm{a}}$ & $170.18 \pm 5.146^{\mathrm{b}}$ & $432.75 \pm 2.237^{\mathrm{a}}$ \\
\hline $\begin{array}{l}\text { G1: bird } \\
\text { G2: bird } \\
\text { G3: con } \\
\text { Means c } \\
\text { significa } \\
\text { Means c }\end{array}$ & $\begin{array}{l}\text { supplemented wi } \\
\text { supplemented wi } \\
\text { ol group } \\
\text { rrying different s } \\
\text { tly different at (P } \\
\text { rrying the same s }\end{array}$ & $\begin{array}{l}\text { nthetized vitamin } \\
\text { nthetized vitamin } \\
\text { cripts in the same } \\
\text { 01). } \\
\text { cripts in the same }\end{array}$ & $\begin{array}{l}5 \mathrm{~g} / \mathrm{L}) . \\
\mathrm{ml} / \mathrm{L}) . \\
\mathrm{mn} \text { are significant } \\
\mathrm{mn} \text { are non-signif }\end{array}$ & $\begin{array}{l}\text { erent at }(\mathrm{P} \leq 0 \\
\text { different at }\end{array}$ & $\begin{array}{l}\text { highly } \\
5) \text {. }\end{array}$ \\
\hline
\end{tabular}

Table 6. Correlation co-efficient of Antioxidant enzymes and Immunoglobulin with Total Bacterial Count (TBC) above diagonal and with Total Enterobacteriaceae Count Below diagonal in group supplemented with Synthetized Vitamin C.

\begin{tabular}{|l|c|c|c|c|c|c|c|c|c|}
\hline \multicolumn{1}{|c|}{ r } & TBC & GSH-Px & GSH-Rx & SOD & r & TBC & IgG & IgM & IgE \\
\hline TEC & $\mathbf{1}$ & $-0.599^{*}$ & 0.465 & 0.312 & TEC & $\mathbf{1}$ & 0.304 & -0.043 & -0.353 \\
\hline GP & 0.469 & $\mathbf{1}$ & -0.439 & -0.027 & IgG & 0.484 & $\mathbf{1}$ & $0.857^{* *}$ & $0.601^{* *}$ \\
\hline GR & 0.265 & -0.439 & $\mathbf{1}$ & -0.046 & IgM & $0.588^{*}$ & $0.857^{* *}$ & $\mathbf{1}$ & $0.780^{* *}$ \\
\hline DOM & -0.029 & -0.027 & -0.046 & $\mathbf{1}$ & IgE & $0.923^{* *}$ & $0.601^{*}$ & $0.780^{* *}$ & $\mathbf{1}$ \\
\hline
\end{tabular}

Table 7. Correlation co-efficient of Antioxidant enzymes and immunoglobulin with Total Bacterial Count (TBC) above diagonal and with Total Enterobacteriaceae Count Below diagonal in group supplemented with Synthetized Vitamin E.

\begin{tabular}{l|l|c|c|c|c|l|c|c|c|c|}
\hline \multicolumn{1}{|c|}{$\mathbf{r}$} & TBC & GSH-Px & GSH-Rx & SOD & r & TBC & IgG & IgM & IgE \\
\hline TEC & $\mathbf{1}$ & 0.501 & -0.302 & -0.148 & TEC & $\mathbf{1}$ & $-0.625^{*}$ & $-0.585^{*}$ & $-0.648^{*}$ \\
\hline GP & -0.401 & $\mathbf{1}$ & 0.411 & -0.009 & IgG & 0.091 & $\mathbf{1}$ & $0.958^{* *}$ & $0.848^{* *}$ \\
\hline GR & 0.016 & 0.411 & $\mathbf{1}$ & -0.524 & IgM & -0.155 & $0.958^{* *}$ & $\mathbf{1}$ & $0.683^{* *}$ \\
\hline DOM & -0.391 & -0.009 & -0.524 & $\mathbf{1}$ & IgE & $0.583^{*}$ & $0.848^{* *}$ & $0.683^{*}$ & $\mathbf{1}$ \\
\hline
\end{tabular}

\section{Discussion:-}

Vitamin C can be synthetized easily as the enzyme systems responsible for its production were formed early enough during the development of life process on earth, that is why the most prominent source of vitamin $\mathrm{C}$ on earth are of plant and animals origin. The quantity and titre of L-ascorbic acid in the human body clears its daily requirement and vitality as nutrients for healthy maintenance; Horning, (1975); Tripathi et al., (2009).

Ascorbic acid (vitamin C) is primarily synthesized in broiler through the kidneys. This synthesis become insufficient during the presence of some stressors as heat stress causing suppressed immunity, lowered feed intake and consequently the performance traits, to some extend lowered body temperature, lowered carcass weight and increase mortality rates; Hu, et al., (2015). The present study showed the improvement caused by the enhancing effects of vitamin $\mathrm{C}$ on broilers performance traits (body weight gain, feed conversion ratio and performance index), but this enhancement was retreated as the broiler advances in age due to the failure of immune barrier imposed by vitamin C.

Broilers are usually adapted the surrounding conditions, but any changes might contributed a great drop in their performance and meat quality; that is why broilers are highly sensitive to the change in the surrounding 
microclimatic conditions (Nolan et al., 1999). A special reference was given to the elevations in ambient temperature; that contributed depressed feed intake, lower weight gain and increased mortality rates; (Ayo et al., 1996). Based on these facts the dietary supplementation of broilers with vitamin $C$ increased adrenal cortex secretion and can alleviate the heat stress influences.

Vitamin $\mathrm{E}$ is a fat soluble vitamin of plant origin that can act as a lipid-soluble antioxidant. It acts in synergism with glutathione peroxidase, catalase, and superoxide dismutase to get rid of the metabolites which were formed during free radical chain reaction; Herrera and Barbas, (2001). Thus, vitamin E was able to prevent the increase accumulation of free radicals and avoid the damage of protein and DNA as well as the fatty acids (poly unsaturated) present on cell membrane; Mézes et al., (1997). Vitamin E has proven the ability to induce immunoregulatory effect, which could be carried out through the modification of cyclooxygenase and lipoxygenase pathways causing exert of a control on the synthesis of prostaglandins and leukotrienes (Leshchinsky and Klasing, 2001).

The present article revealed the superiority of vitamin $\mathrm{E}$ compared to vitamin $\mathrm{C}$ in the immune stimulating effects and antibacterial action. Rice and Kennedy, (1988) suggested that the advantage of higher levels of dietary vitamin E will be witnessed mainly when the group is exposed to some kind of stressor. The absence of differences in the growth performance among the 5 dietary treatments in this study indicates that all the birds might have been exposed to stress below the threshold level to get a beneficiary effect from higher levels of dietary vitamin E on growth performance and yield.

\section{Conclusion:-}

Synthetized vitamin $\mathrm{E}$ and vitamin $\mathrm{C}$ were able to enforce a protective effect in the birds which last for only 4 week then vanished gradually. Synthetized Vitamin E was superior to vitamin C in enforcing a good protective effect on the birds. A final recommendation is advised to maintain the supplementations on a higher levels and longer period to maintain its influences on the birds.

\section{References:-}

1. Agius, F., González-Lamothe, R., Caballero, J.L., Muñoz-Blanco, J., Botella, M.A., Valpuesta, V. (2003). Engineering increased vitamin $\mathrm{C}$ levels in plants by overexpression of a D-galacturonic acid reductase. Nature Biotechnology 2003, 21(2): 177-181.

2. Altan, O., Pabuccuoglu, A., Altan, A., Konyalioglu, S., Bayraktar, H. (2003). Effect of heat stress on oxidative stress, lipid peroxidation and some stress parameters in broilers. Br. Poult. Sci. 44(4):545-550.

3. Ayo, J.O., Oladele, S.B., Fayomi, A. (1996). Effect of heat stress on livestock production: A review. Nigerian Veterinary Journal 58-68, Special edition, 1(1): 58-68.

4. Bautista-Ortega, J., Cortes-Cuevas, A., Ellis, E.A., Ruiz-Feria, C.A. (2014). Supplemental L-arginine and vitamins $\mathrm{E}$ and $\mathrm{C}$ preserve xanthine oxidase activity in the lung of broiler chickens grown under hypobaric hypoxia. Poult. Sci.;93(4):979-988

5. Berne, G.H. (1974). Clin. Chem. 200, 61-89.

6. Bottje, W.G., Wang, S., Kelly, F.J., Dunster, C., Williams, A., Mudway, I. (1998). Antioxidant defenses in lung lining fluid of broilers: Impact of poor ventilation conditions. Poult. Sci. 77(4):516-522.

7. Cruickshank, R., Duguid, J.P., Marimion, B.P., Swain, R.H. (1975). Medical Microbiology, the Practice of Medical Microbiology. 12th Ed, Vol. 11, Churchill Livingstone Limited, Edinburgh, London and New York.

8. Cruickshank, R., Duguid, J.P., Marimion, B.P., Swain, R.H. (1980). Medical Microbiology. E.L.B.S., $12^{\text {th }}$ Ed, Vol. 11, Reprinted Churchill Livingstone and Robert Stevenson, Edinburgh, EHI, 3AF.

9. Davey, M.W., Montagu, M.V., Inze, D., Sanmartin, M., Kanellis, A., Smirnoff, N., Benzie, I.J.J., Strain, J.J., Favell, D., Fletcher, J. (2000). Plant L-ascorbic acid: chemistry, function, metabolism, bioavailability and effects of processing. J. Sci. Food Agric., 80, 825-860.

10. Ghazi, S., Amjadian, T., Norouzi, S. (2015). Single and combined effects of vitamin C and oregano essential oil in diet, on growth performance, and blood parameters of broiler chicks reared under heat stress condition. Int. J. Biometeorol.; 59(8):1019-24.

11. Goldberg, D.M., Spooner, R.J. (1983). Methods of enzymatic analysis (Bergmeyen, HV Ed.) $3^{\text {rd }}$ edn. Vol 3, 258-265, verlog chemie, Deerfield beach, Fl.

12. Halliwell, B., Gutteridge, J.M.C. (2000). Free Radicals in Biology and Medicine. 3rd ed Oxford Univ. Press; New York, NY, USA.

13. Heremans, J.P., Masson, P.L. (1973). Clin. Chem. 19:294-300. 
14. Herigstad, B., Hamilton, M., Heersink, J. (2001). How to optimize the drop plate method for enumerating bacteria. J. Microbiol. Meth. 44(2):121-129.

15. Herrera, E., Barbas, C. (2001). Vitamin E: Action, metabolism and perspectives. J. Physiol. Biochem. 57:43-56.

16. Horning, D. (1975). Ann. NY. Acad. Sci. 258: 103.

17. Hu, Z.P., Wang, T., Ahmad, H., Zhang, J.F., Zhang, L.L., Zhong, X. (2015). Effects of different formulations of $\alpha$-tocopherol acetate (vitamin E) on growth performance, meat quality and antioxidant capacity in broiler chickens. Br Poult. Sci.; 56(6):687-695.

18. Kaiser, M.G., Block, S.S., Ciraci, C., Fang, W., Sifri, M., Lamont, S.J. (2012). Effects of dietary vitamin E type and level on lipopolysaccharide-induced cytokine mRNA expression in broiler chicks. Poult. Sci. 91(8):18931898.

19. Lauridsen, C., Engel, H., Jensen, S.K., Craig, A.M., Traber, M.G. (2002). Lactating sows and suckling piglets preferentially incorporate RRR-over all-rac- $\alpha$-tocopherol into milk, plasma and tissues. J. Nutr. 132(6):12581264.

20. Leshchinsky, T.V., Klasing, K.C. (2001). Relationship between the level of dietary vitamin E and the immune response of broiler chickens. Poult. Sci. 80:1590-1599.

21. Levesque, (2007). SPSS Programming and Data Management: A Guide for SPSS and SAS Users, Fourth Edition (2007), SPSS Inc., Chicago Ill.

22. Mezes, M., Surai, P., Salyi, G., Speake, B.K., Gaal, T., Maljian, A. (1997). Nutritional metabolic diseases of poultry and disorders of the biological antioxidant defence system. Acta Vet. Hung. 45:349-360.

23. Nishikimi, M., Roa, N.A., Yogi, K. (1972). Biochem. Bioph. Res. Coomon., 46: 849-854.

24. Nolan, J., Hinch, G., Twaite, S.J., Walkden-Brown, S. (1999). Constrains to animal production, Chapter 2: Climatic constrains, Lecturer Paper 12, Animal Science Group Publisher, Australia.

25. Odinokov, V.N., Spivak, A.Y., Emelyanova, G.A., Mallyabaeva, M.I., Nazarova, O.V., Dzhemilev, UM. (2003). Synthesis of $\alpha$-tocopherol (vitamin E), vitamin K1-chromanol, and their analogs in the presence of aluminosilicate catalysts Tseokar-10 and Pentasil. ARKIVOC (xiii): 101-118.

26. Paglia, D.E., Valentine, W.N. (1967). J. Lab. Clin. Med. 70: 158-169.

27. Rafiee, F., Mazhari, M., Ghoreishi, M., Esmaeilipour, O. (2016). Effect of lemon verbena powder and vitamin $\mathrm{C}$ on performance and immunity of heat-stressed broilers. J. Anim. Physiol. Anim. Nutr. doi: 10.1111/jpn.12457.

28. Rey, A.I., Segura, J., Olivares, A., Cerisuelo, A., Piñeiro, C., López-Bote, C.J. (2015). Effect of micellized natural (D- $\alpha$-tocopherol) vs. synthetic (DL- $\alpha$-tocopheryl acetate) vitamin E supplementation given to turkeys on oxidative status and breast meat quality characteristics. Poult. Sci.; 94(6):1259-1269.

29. Rice, D.A., Y.S. Kennedy. (1988). Vitamin E and free radical formation. Pages 39-57 in Recent Advances in Animal Nutrition. W. Haresign and D.J.A. Cole, ed. Butterworths, London, UK.

30. Sahin, K., Sahin, N., Sari, M., Gursu, M.F. (2002). Effects of vitamins E and A supplementation on lipid peroxidation and concentration of some mineral in broilers reared under heat stress $\left(32^{\circ} \mathrm{C}\right)$. Nutr. Res. $22: 723-$ 731.

31. Tripathi, R.P., Singh, B., Bisht, S.S., Pandey, J. (2009). L-Ascorbic acid in Organic Synthesis: An Overview. Current Organic Chemistry 13: 99-122.

32. Voljč, M., Frankič, T., Levart, A., Nemec, M., Salobir, J. (2011). Evaluation of different vitamin E recommendations and bioactivity of $\alpha$-tocopherol isomers in broiler nutrition by measuring oxidative stress in vivo and the oxidative stability of meat. Poult. Sci. 90(7):1478-1488.

33. Young, D.S. (1995). Effects of drugs on clinical lab. Tests, 4th ed, AACC Press.

34. Young, D.S. (2001). Effects of disease on clinical lab. Tests, 4th ed, AACC Press.

35. Zelver, N., Hamilton, M., Pitts, B., Goeres, D., Walker, D., Sturman, P., Heersink, J. (1999). Measuring antimicrobial effects on biofilm bacteria: in R. J. Doyle, et al. (eds), biofilm: methods in enzymology. Academic Press, San Diego, CA, pp. 608-628. 